\title{
Clinical Study \\ Pyoderma Gangrenosum: A Review of Clinical Features and Outcomes of 23 Cases Requiring Inpatient Management
}

\author{
Mingwei Joel Ye $e^{1,2}$ and Joshua Mingsheng $\mathbf{Y e}^{2}$ \\ ${ }^{1}$ Department of Dermatology, Western Hospital, Footscray, VIC 3011, Australia \\ ${ }^{2}$ Department of Medicine, Dentistry and Health Sciences, University of Melbourne, Parkville, VIC 3010, Australia \\ Correspondence should be addressed to Mingwei Joel Ye; joelye_85@hotmail.com
}

Received 18 August 2014; Revised 22 September 2014; Accepted 24 September 2014; Published 8 October 2014

Academic Editor: Jane M. Grant-Kels

Copyright (c) 2014 M. J. Ye and J. M. Ye. This is an open access article distributed under the Creative Commons Attribution License, which permits unrestricted use, distribution, and reproduction in any medium, provided the original work is properly cited.

\begin{abstract}
Pyoderma gangrenosum (PG) is a rare dermatological disorder characterised by the rapid progression of a painful, necrolytic ulcer. This study retrospectively identified patients who were admitted and treated for PG during a 10-year period (2003-2013). Twentythree patients were included in this study, 16 women and seven men. The mean age at initial admission was 62.8 years (range 30 to 89 years). Lesions were localised to lower limb in 13 patients, peristomal region in four, breast in three, and upper limb in one, and two patients had PG at multiple sites. The variants of PG noted were ulcerative (18), bullous (2), vegetative (2), and pustular (1). Associated systemic diseases were observed in 11 patients $(47.8 \%)$. Systemic therapies were initiated in 21 patients while two patients received topical treatments. The mean length of hospital stay was 47 days (range 5 to 243 days) and five patients died during their admissions. Seven patients required readmissions for exacerbations of their PG. Our study showed that patients admitted for treatment of PG had high morbidity and mortality. This study also highlights the importance of early and aggressive treatment of patients admitted with PG as well as treating associated systemic diseases and wound infections.
\end{abstract}

\section{Introduction}

Pyoderma gangrenosum (PG) is a rare dermatological condition that was first described by Brocq, a French dermatologist, in 1916 [1]. It is characterized by rapidly, progressing ulceration of the skin with an ill-defined border and can occur at any age, but more frequently observed in adults than children [2]. It has a gender predilection for females [3] and commonly affects the lower extremities, in particular the pretibial area $[2,3]$.

The etiology of PG remains unknown but has been attributed to reactive neutrophilic dermatosis. Pathergy, a term used to describe an exaggerated skin injury occurring after trauma, can exacerbate PG [2]. Diagnosis of PG requires clinicopathologic correlation and is often a diagnosis of exclusion after common causes of skin ulceration such as infection, malignant neoplasms, and vasculitic syndromes have been ruled out. Histopathological findings of PG are not specific. Early lesions may reveal dermal neutrophilia centered on follicles, while severe skin lesions may show tissue necrosis with surrounding mononuclear cell infiltrates [2]. PG is often associated with systemic diseases such as inflammatory bowel disease (IBD), rheumatoid, and haematological conditions [4-6].

Systemic therapy such as corticosteroids and cytotoxic agents are the treatment of choice for rapidly progressing PG $[7,8]$. Newer biological agents such as infliximab and adalimumab have also been found to be effective $[9,10]$. Despite advances in medical therapy, the prognosis of PG remains unpredictable and, if left untreated, almost always fatal. This retrospective study was undertaken to strengthen current knowledge and experience of the outcomes of PG, as well as identifying possible factors that may exert influence over patients' outcomes.

\section{Methods}

In this study, we retrospectively analysed the characteristics of patients who were treated for PG. Twenty-three patients who were admitted and treated for PG were identified from Western Hospital Health Information Service through 
TABLE 1: Demographics of 23 patients admitted with PG.

\begin{tabular}{lc}
\hline Demographics & Number of cases (\%) \\
\hline Age at diagnosis (years) & 4 \\
$30-44$ & 4 \\
$45-59$ & 10 \\
$60-74$ & 5 \\
75 and above & 62.8 years (30-89) \\
Mean age at diagnosis (range) & 7 \\
Sex & 16 \\
Male & 11 \\
Female & \\
Associated disease & 2 \\
Treatment & 21 \\
Topical & 47 days (5-243) \\
Systemic & \\
Mean length of hospital stay (range) & 18 \\
Outcome & 5 \\
Alive after 1st admission & 7 \\
Dead at lst admission & \\
Recurrence &
\end{tabular}

a search of medical records over a 10 -year period from July 2003 to September 2013.

The medical records of these patients were reviewed and the following data were extracted: age at initial hospital admission for PG, sex, clinical variant of PG, site of ulcer, associate systemic diseases, investigation results, treatment regimes, and outcomes including length of hospital stay, deaths, and recurrence during follow-up.

\section{Results}

3.1. Patient Demographics. Twenty-three patients (see Table 1) were included in this study between July 2003 and September 2013. All patients were admitted for inpatient management of PG. One patient also suffered from community acquired pneumonia at the time of admission. There were 16 women and seven men (ratio of $2.3: 1$ ) and the mean age of onset was 62.8 years (range 30 to 89 years). The mean age of onset was 63.6 years for women and 61 years for men. The peak incidence of onset of PG was in the seventh decade $(n=6,26 \%)$.

3.2. Clinical Features. Ulcerative PG was the most common variant and was observed in 18 patients $(78.3 \%)$, vegetative PG in two (8.7\%), and bullous PG in two (8.7\%) and one patient suffered from pustular PG (4.3\%). The lower limb was the commonest site of PG occurrence $(n=13,56.5 \%)$ (see Figure 1). For the rest of the patients, lesions developed on the breasts in three patients (13\%), peristomal area in four patients (17.4\%), and upper limb in one patient (4.4\%) and two patients had lesions in multiple sites (8.7\%). Ten patients reported trauma as a precipitating cause of PG. Of these, surgery accounted for six cases.
Other associated systemic diseases were found in 11 patients (47.8\%), five cases with solid tumours (three bowel and two lung cancers), two with IBD (Crohn's disease and ulcerative colitis), two with connective tissue joint diseases (CREST and ankylosing spondylitis), and two with haematological disorders (essential thrombocythemia and monoclonal gammopathy).

3.3. Investigations. Wound swabs and C-reactive protein (CRP) were performed on admission. Microbiological study of swabs from the ulcers revealed positive cultures in 13 patients (56.5\%). Staphylococcus aureus was found in five, Enterococci in one, Escherichia coli in two, Streptococci in four, Pseudomonas aeruginosa in three, and Serratia marcescens in one. The CRP values of our patients ranged from $3 \mathrm{mg} / \mathrm{L}$ to $474 \mathrm{mg} / \mathrm{L}$ (normal reference interval, $0-10 \mathrm{mg} / \mathrm{L}$ ).

In order to exclude other causes of skin ulceration and identify underlying systemic diseases, the patients also underwent a range of laboratory tests including a full blood examination, serum electrolytes, immunoelectrophoresis, antinuclear antibodies, and rheumatoid factor. Additional tests such as hepatitis serology, antineutrophilic cytoplasmic antibodies, and extractible nuclear antigen were performed in some patients according to clinical suspicion and initial investigation results. None of our patients had a positive vasculitis test. One patient had oligoclonal banding in gamma region on immunoelectrophoresis and was subsequently diagnosed with monoclonal gammopathy.

The results of skin biopsies were available for 15 patients. Neutrophil infiltration to deep dermis was seen in 12 cases, lymphocytic infiltrate in six, abscess formation in three, vasculitis in one, and leukocytoclasia in one.

3.4. Treatment. Systemic therapy was used in 21 patients (91.3\%). Systemic therapy involved either monotherapy with prednisolone (dose of $25 \mathrm{mg}-50 \mathrm{mg}$ daily) in eight patients or combination therapy (see Figure 2) which consisted of at least prednisolone and other treatments such as tetracycline, dapsone, azathioprine, mycophenolate mofetil (MMF), and adalimumab. Potent topical steroids such as betamethasone dipropionate and mometasone furoate were used in two patients $(8.7 \%)$.

Seven patients underwent surgical interventions while on immunosuppressive therapy. Five patients had minor debridement of their wounds, one patient had split skin grafts (SSG), and another had both SSG and minor debridement. None of the patients had exacerbation after these procedures.

Intravenous antibiotics were administered to 18 patients based on clinical suspicion of infected PG wound.

\subsection{Patient Outcomes}

3.5.1. Length of Stay (LOS). Mean length of hospital stay (LOS) till discharge or death was 47 days (range 5 to 243 days). Three patients were hospitalised for more than three months. All three suffered from concomitant wound infections during their hospital stay. Two of them grew Staphylococcus aureus and one grew Extended-spectrum beta-lactamase (ESBL) 
TABLE 2: Characteristics of patients who died during initial admission.

\begin{tabular}{|c|c|c|c|c|c|c|c|c|c|}
\hline \multicolumn{2}{|c|}{ Age/sex LOS (days) } & \multirow{2}{*}{$\begin{array}{c}\text { Site } \\
\begin{array}{c}\text { Lower } \\
\text { limb }\end{array}\end{array}$} & \multirow{2}{*}{$\begin{array}{c}\text { Type } \\
\text { Ulcerative }\end{array}$} & \multirow{2}{*}{$\begin{array}{c}\begin{array}{c}\text { Associated } \\
\text { disease }\end{array} \\
\begin{array}{c}\text { Lung and } \\
\text { prostate cancer }\end{array}\end{array}$} & \multirow{2}{*}{$\begin{array}{c}\text { Other } \\
\text { comorbidities } \\
\text { Atrial } \\
\text { fibrillation, } \\
\text { osteoporosis }\end{array}$} & \multirow{2}{*}{$\begin{array}{l}\text { Wound culture } \\
\text { Pseudomonas }\end{array}$} & \multirow{2}{*}{$\begin{array}{c}\text { CRP } \\
65\end{array}$} & \multirow{2}{*}{$\begin{array}{c}\text { Treatment } \\
\begin{array}{c}\text { Prednisolone, } \\
\text { MMF }\end{array}\end{array}$} & \multirow{2}{*}{$\begin{array}{c}\begin{array}{c}\text { Cause of } \\
\text { death }\end{array} \\
\text { Sepsis }\end{array}$} \\
\hline $85 \mathrm{M}$ & 20 & & & & & & & & \\
\hline $81 \mathrm{~F}$ & 15 & $\begin{array}{l}\text { Lower } \\
\operatorname{limb}\end{array}$ & Vegetative & - & - & $\begin{array}{l}\text { Streptococcus, } \\
\text { Enterococcus }\end{array}$ & 88 & $\begin{array}{l}\text { Prednisolone, } \\
\text { minocycline }\end{array}$ & Sepsis \\
\hline $72 \mathrm{~F}$ & 151 & $\begin{array}{l}\text { Lower } \\
\text { limb }\end{array}$ & Ulcerative & Colon cancer & $\begin{array}{l}\text { Aortic valve } \\
\text { replacement, } \\
\text { osteoarthritis }\end{array}$ & Staphylococcus & 178 & $\begin{array}{l}\text { Prednisolone, } \\
\text { dapsone, MMF, } \\
\text { and doxycycline }\end{array}$ & Sepsis \\
\hline $72 \mathrm{~F}$ & 38 & $\begin{array}{l}\text { Lower } \\
\text { limb }\end{array}$ & Ulcerative & CREST & $\begin{array}{l}\text { Osteoporosis, } \\
\text { hypertension }\end{array}$ & Staphylococcus & 111 & Prednisolone & $\begin{array}{l}\text { Multiorgan } \\
\text { failure }\end{array}$ \\
\hline $83 \mathrm{M}$ & 29 & $\begin{array}{l}\text { Lower } \\
\text { limb }\end{array}$ & Ulcerative & $\begin{array}{l}\text { Monoclonal } \\
\text { gammopathy }\end{array}$ & $\begin{array}{l}\text { Psoriasis, gout, } \\
\text { hypertension, } \\
\text { and } \\
\text { osteoporosis }\end{array}$ & $\begin{array}{l}\text { Pseudomonas, } \\
\text { Staphylococcus }\end{array}$ & 52 & $\begin{array}{l}\text { Prednisolone, } \\
\text { azathioprine }\end{array}$ & Sepsis \\
\hline
\end{tabular}

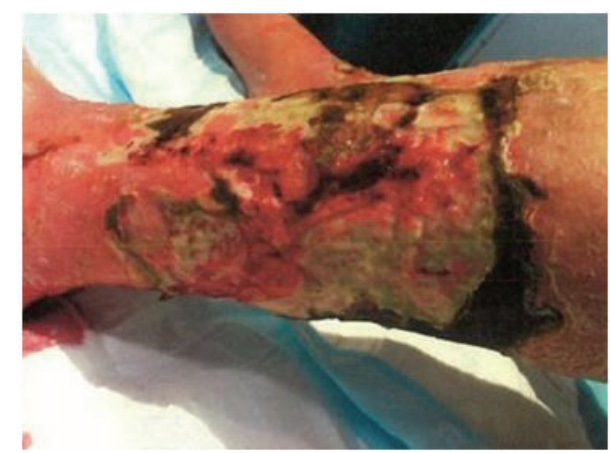

(a)

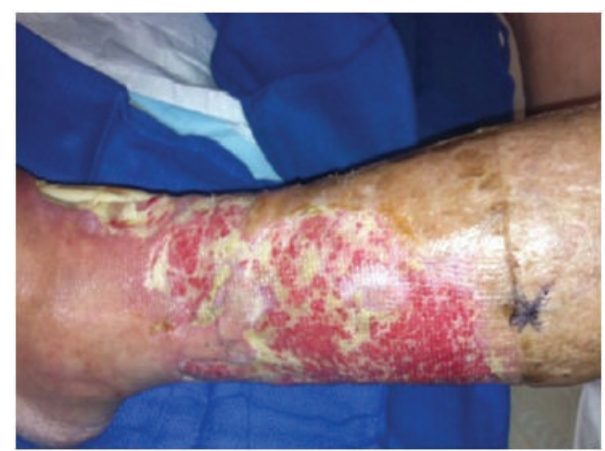

(b)

FIGURE 1: (a) 73-year-old female with bilateral lower limb ulcerative PG and colorectal cancer. (b) Epithelialization and granulation tissue formation after 3 months of prednisolone $30 \mathrm{mg} /$ daily and mycophenolate mofetil $1 \mathrm{~g} /$ twice daily.

Escherichia coli. All three patients had abnormally high CRP levels (range $53 \mathrm{mg} / \mathrm{L}-178 \mathrm{mg} / \mathrm{L}$ ) and one patient who also suffered from colorectal cancer died during the initial hospital admission.

3.5.2. Death. Five patients $(21.7 \%)$ died during their initial hospital stay (see Table 2). Their mean age at time of admission was 78.8 years (range 72 to 85 years). The mean LOS till death was 50.6 days (range 15 to 151 days). All had lower limb PG. The cause of death was sepsis in four patients while one patient died of multiorgan failure secondary to hypovolemia. Four patients had ulcerative and one had vegetative PG. All patients had positive wound cultures and all had highly elevated CRP levels above $50 \mathrm{mg} / \mathrm{L}$. Four patients had associated systemic disease. All underwent systemic therapy: three had combination therapy while two had monotherapy.

3.5.3. Recurrence. Seven patients had recurrence of PG requiring readmission (see Table 3 ). The mean number of readmissions for $\mathrm{PG}$ was three (range 1 to 7 ). Three patients died during their subsequent admissions. The mean age at diagnosis of the patients who died during subsequent admissions was 68 years. Of those who died, two patients had concomitant gastrointestinal disorders.

\section{Discussion}

4.1. Patient Demographics. We retrospectively reviewed 23 patients diagnosed with PG and treated at our hospital over a 10 -year period. The mean age of onset was 62.8 years which was similar to that reported in two recent studies [11, 12]. Three earlier studies reported an earlier mean age of onset with peak incidence in the fifth to sixth decade [13-15]. It is widely known that PG has a predilection for females [3] and our study has shown a similar result.

4.2. Clinical Features. Four variants have been described in the literature, namely, ulcerative [2], vegetative [16], bullous [6], and pustular [17]. Ulcerative PG, which is the classical variant, is the commonest form in our study as well as previous studies $[11-15,18]$. It is characterised by the appearance of a painful, irregular ulcer with a violaceous border [2]. The other variants of PG are less common and usually respond well to immunosuppressive treatments [3]. In our study, the 


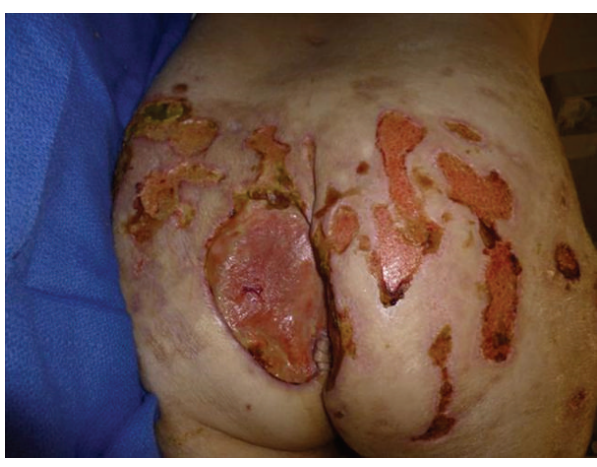

(a)

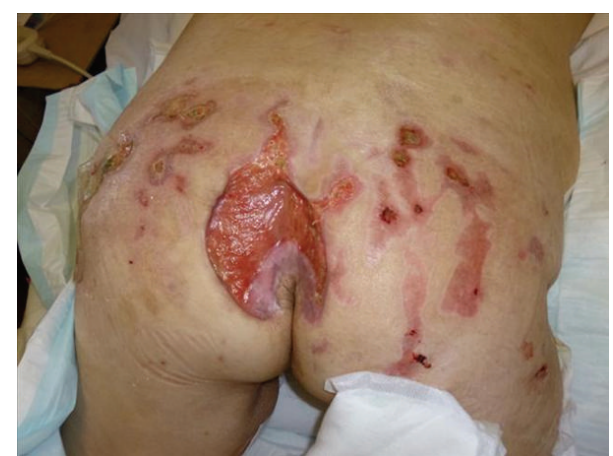

(b)

FIgURE 2: (a) 51-year-old female with PG at multiple sites including sacrum. (b) Resolution of smaller lesions after 1 month of prednisolone $50 \mathrm{mg} /$ daily and mycophenolate mofetil $1 \mathrm{~g} /$ twice daily.

lesions were more commonly localised to the lower limbs (56.5\%) but this proportion was lower than other studies which reported a proportion of $70 \%$ to $80 \%[3,12,13,15]$. Pathergy was a precipitating factor in almost half the cases. One of the main causes of pathergy was surgery. It is therefore critical for clinicians to be aware and vigilant in diagnosing this complication as delayed diagnosis can potentially lead to poorer prognosis.

Many studies have reported that, in 50 to $70 \%$ of the cases, PG is associated with an underlying disease such as IBD, inflammatory arthritis, haematological disorders, and solid malignancies [11-15]. In our study, $47.8 \%$ of patients had associated systemic diseases. Most patients presented with known systemic disorders. Only one patient was newly diagnosed with an associated systemic disease during the acute admission. He was diagnosed with monoclonal gammopathy on serum protein electrophoresis. This highlights the importance of screening patients with PG for associated systemic diseases.

4.3. Investigations. It is not uncommon for PG to occur with wound infection. We observed that CRP alone is not specific for wound infection $[6,19,20]$. An elevated CRP can indicate either a concomitant bacterial infection or active inflammatory process associated with PG. However, an abnormally high level of CRP more than $50 \mathrm{mg} / \mathrm{L}$, a positive wound culture, and clinical signs such as erythema and swelling indicate a wound infection which should prompt treatment with antibiotics. Immunosuppression should still be continued to prevent progression of PG $[6,19,20]$ except in the presence of systemic sepsis. CRP is a valuable investigation and has been shown in previous studies to be useful in monitoring progression of PG [11].

Histology findings are nonspecific but can serve to exclude infection, malignancy, and vasculitis [2]. Neutrophilic infiltration into dermis is the histological hallmark of PG [2] and is consistent with the results of our study. Other histological findings of leukocytoclasia, abscess, and vasculitis are also seen in our patients.
4.4. Treatment. Systemic therapy is the mainstay of treatment for severe, progressive PG which is commonly seen in patients requiring hospital treatment for PG $[7,8]$. Twentyone patients received systemic therapy. Only two patients with mild PG received topical therapy and were discharged after a relatively short hospital stay. One patient was admitted as she was also suffering from community acquired pneumonia while the other had peristomal PG and required admission to monitor his underlying Crohn's disease.

Systemic corticosteroids have been shown to be effective in a number of studies and are therefore considered as firstline therapy $[7,8]$. Combination therapy of corticosteroid and other immunosuppressive agents can be used to avoid higher doses of steroids and thus reduce the side effects associated with high doses of steroids [8]. Recently, it has been shown that antitumour necrosis factor drugs such as infliximab and adalimumab are successful in treating PG associated with IBD $[9,10]$. In our study, only 1 patient received such therapy, 33-year-old female patient who was on multiple systemic immunosuppressive agents including prednisolone, MMF, azathioprine, and adalimumab. Her response to the drugs was less than satisfactory and she had six readmissions in nine months for exacerbations of lower limb PG.

Surgical intervention can worsen PG through pathergy $[2,19,20]$. Therefore, surgical intervention such as SSG should only be performed in conjunction with immunosuppression. Mild debridement of necrotic tissue may prevent bacterial infections. All our patients who underwent SSG or debridement while on immunosuppressive therapy did not have any documented evidence of postoperative exacerbation of the skin disease.

4.5. Patient Outcomes. A literature search revealed little information on the prognosis of patients who were admitted for treatment of PG. Our study revealed that patients had lengthy hospital admissions (mean LOS: 47 days), high death $(21.7 \%)$, and recurrence rates (39\%). Patients who were admitted to hospital for treatment tended to have severe and aggressive PG. There are some factors which can affect the prognosis of PG. Reichrath et al. suggested that the type 
TABLE 3: Characteristics of patients who survived initial admission.

\begin{tabular}{|c|c|c|c|c|c|c|}
\hline Age/sex & Site & Type & Associated disease & Other comorbidities & Treatment & Recurrence \\
\hline $67 \mathrm{M}$ & Lower limb & Ulcerative & Ulcerative colitis & $\begin{array}{l}\text { Stroke, hypertension, } \\
\text { atrial fibrillation, and } \\
\text { smoker }\end{array}$ & Prednisolone & Yes \\
\hline $45 \mathrm{M}$ & Upper limb & Ulcerative & - & $\begin{array}{c}\text { Hypertension, } \\
\text { hypercholesterolaemia, } \\
\text { depression, and } \\
\text { obstructive sleep apnoea }\end{array}$ & $\begin{array}{l}\text { Prednisolone, } \\
\text { doxycycline }\end{array}$ & Yes \\
\hline $66 \mathrm{M}$ & Peristomal & Vegetative & Crohn's disease & $\begin{array}{l}\text { Ischaemic heart disease, } \\
\text { hypertension, and peptic } \\
\text { ulcer }\end{array}$ & $\begin{array}{l}\text { Mometasone furoate } \\
\text { ointment }\end{array}$ & Yes \\
\hline $30 \mathrm{M}$ & Multiple & Bullous & $\begin{array}{l}\text { Ankylosing } \\
\text { spondylitis }\end{array}$ & - & $\begin{array}{l}\text { Prednisolone, } \\
\text { dapsone }\end{array}$ & Yes \\
\hline $70 \mathrm{~F}$ & Lower limb & Ulcerative & - & $\begin{array}{c}\text { Diabetes type 2, } \\
\text { hypertension, } \\
\text { hypercholesterolaemia, } \\
\text { ischaemic heart disease, } \\
\text { congestive cardiac } \\
\text { failure, and atrial } \\
\text { fibrillation }\end{array}$ & $\begin{array}{l}\text { Prednisolone, } \\
\text { minocycline }\end{array}$ & Yes \\
\hline $33 \mathrm{~F}$ & Lower limb & Pustular & - & Obesity & $\begin{array}{c}\text { Prednisolone, } \\
\text { azathioprine, } \\
\text { adalimumab, and } \\
\text { MMF }\end{array}$ & Yes \\
\hline $53 \mathrm{~F}$ & Lower limb & Ulcerative & - & Obesity, osteoarthritis & $\begin{array}{l}\text { Prednisolone, } \\
\text { azathioprine }\end{array}$ & Yes \\
\hline $71 \mathrm{~F}$ & Lower limb & Ulcerative & - & $\begin{array}{c}\text { Diabetes type 2, } \\
\text { hypothyroidism, and } \\
\text { peripheral vascular } \\
\text { disease }\end{array}$ & Prednisolone & No \\
\hline $72 \mathrm{~F}$ & Lower limb & Ulcerative & - & $\begin{array}{c}\text { Diabetes type } 2, \\
\text { hypertension, and } \\
\text { hypercholesterolaemia }\end{array}$ & $\begin{array}{l}\text { Betamethasone } \\
\text { dipropionate } \\
\text { ointment }\end{array}$ & No \\
\hline $51 \mathrm{~F}$ & Multiple & Ulcerative & - & $\begin{array}{c}\text { Diabetes type } 2 \text {, chronic } \\
\text { obstructive airways } \\
\text { disease, } \\
\text { hypercholesterolaemia, } \\
\text { hypertension, and } \\
\text { peripheral vascular } \\
\text { disease }\end{array}$ & $\begin{array}{l}\text { Prednisolone, MMF, } \\
\text { and skin grafts }\end{array}$ & No \\
\hline $80 \mathrm{~F}$ & Peristomal & Ulcerative & Colon cancer & $\begin{array}{c}\text { Hypertension, } \\
\text { Guillain-Barre } \\
\text { syndrome, diabetes type } \\
2 \text {, and osteoarthritis }\end{array}$ & $\begin{array}{l}\text { Prednisolone, } \\
\text { minocycline }\end{array}$ & No \\
\hline $73 \mathrm{~F}$ & Peristomal & Ulcerative & Lung cancer & $\begin{array}{l}\text { Hypertension, } \\
\text { hypercholesterolaemia, } \\
\text { and osteoarthritis }\end{array}$ & $\begin{array}{l}\text { Prednisolone, } \\
\text { doxycycline }\end{array}$ & No \\
\hline $41 \mathrm{~F}$ & Breast & Ulcerative & - & - & Prednisolone & No \\
\hline $60 \mathrm{~F}$ & Peristomal & Ulcerative & Colon cancer & $\begin{array}{c}\text { Hypertension, ischaemic } \\
\text { heart disease, and } \\
\text { asthma }\end{array}$ & Prednisolone & No \\
\hline $51 \mathrm{M}$ & Lower limb & Ulcerative & - & $\begin{array}{c}\text { Diabetes type 2, } \\
\text { ischaemic heart disease }\end{array}$ & Prednisolone & No \\
\hline $37 \mathrm{~F}$ & Breast & Ulcerative & - & - & Prednisolone & No \\
\hline $62 \mathrm{~F}$ & Breast & Ulcerative & - & $\begin{array}{c}\text { Rheumatic heart disease, } \\
\text { congestive cardiac } \\
\text { failure, and atrial } \\
\text { fibrillation }\end{array}$ & $\begin{array}{l}\text { Prednisolone, } \\
\text { doxycycline }\end{array}$ & No \\
\hline
\end{tabular}


TABLE 3: Continued.

\begin{tabular}{|c|c|c|c|c|c|c|}
\hline Age/sex & Site & Type & Associated disease & Other comorbidities & Treatment & Recurrence \\
\hline $89 \mathrm{~F}$ & Lower limb & Bullous & $\begin{array}{c}\text { Essential } \\
\text { thrombocytopenia }\end{array}$ & $\begin{array}{c}\text { Diabetes type 2, } \\
\text { hypertension, } \\
\text { hypercholesterolaemia, } \\
\text { osteoporosis, and } \\
\text { peripheral vascular } \\
\text { disease }\end{array}$ & $\begin{array}{l}\text { Prednisolone, skin } \\
\text { graft }\end{array}$ & No \\
\hline
\end{tabular}

and severity of the associated systemic disease can affect the prognosis of PG [8]. Unresponsiveness of the associated disease to treatment resulted in a poorer prognosis. This is consistent with our findings in which $80 \%$ of the patients who died in our study had an associated systemic disease. Age is also a strong prognostic factor. The mean age of patients who died in our study was 78.8 years, 16 years older than the mean age of patients recruited for our study. In addition, the patients who died in subsequent readmissions were also old, with a mean age of 68 years at time of diagnosis of PG.

Our results also suggest a possible correlation between infected PG wounds and poorer prognosis which has never been reported in the literature. All the patients who died in our study had findings suggestive of infected lower limb PG and the cause of death was sepsis in $80 \%$ of the cases. We noted that patients with infected PG also had prolonged hospital stays. Infected PG requires urgent treatment with antibiotics and continuation of immunosuppressive medications. Reichrath et al. reported the use of topical treatments such as antiseptic or occlusive dressings in preventing wound infections [8]. However, none of these topical treatments have been used on our study patients.

Ulcerative variant of PG is more likely to be associated with poorer prognosis than other variants [3]. In our study, $80 \%$ of patients who died during initial admission had ulcerative PG. Corticosteroids remain the primary immunosuppressive treatment $[7,8]$. Both monotherapy and combination therapy have similar efficacies in the treatment of aggressive PG [8]. Topical corticosteroid can be effective in treatment for small and superficial ulcers [8] and this is shown in the treatment of two of our patients with mild nonulcerative PG who received betamethasone dipropionate twice a day. Recurrence of PG requiring inpatient management was quite high (39\%). Patients with lower limb PG are more likely to have recurrent PG requiring hospital admission. This highlights the importance of long term monitoring and follow-up in this group of patients.

4.6. Limitations. Due to the small sample size of this study, the results were not statistically analysed. PG is a rare disorder and recruiting large number of patients is extremely difficult. Other PG studies had similar number of cases to our study and all their results were not statistically significant [11-15]. Another limitation of our study is that not all our cases had wound biopsies. This raises the possibility of information bias occurring-the ulcers in patients who did not have wound biopsies may be caused by other conditions such as vasculitis and malignancy since PG is a diagnosis of exclusion. We felt that this possibility is quite low as the diagnoses of PG in all cases were made by dermatologists and vasculitic blood tests were negative.

\section{Conclusion}

The findings of our study suggest a poor outlook for patients with PG requiring hospital admission, with long hospital stays, high death, and recurrence rates. Factors possibly associated with poorer prognosis are age, ulcerative variant of PG, presence of associated systemic disease, high CRP levels, and clinical signs of wound infections. It is hence important to treat modifiable factors such as associated systemic diseases and wound infections. The presence of abnormally high CRP levels on admission and clinical features of infection are highly suggestive of infected PG and require a combination of intravenous broad-spectrum antibiotics and immunosuppression.

\section{Conflict of Interests}

The authors declare that there is no conflict of interests regarding the publication of this paper.

\section{Acknowledgment}

The authors wish to thank Professor Edward Janus for his helpful discussion and critical appraisal of their paper.

\section{References}

[1] L. Brocq, "A new contribution to the study of geometric phagedenism," Annales de Dermatologie et de Syphiligraphie, vol. 9, pp. 1-39, 1916.

[2] W. P. D. Su, M. D. P. Davis, R. H. Weenig, F. C. Powell, and H. O. Perry, "Pyoderma gangrenosum: clinicopathologic correlation and proposed diagnostic criteria," International Journal of Dermatology, vol. 43, no. 11, pp. 790-800, 2004.

[3] M. L. Bennett, J. M. Jackson, J. L. Jorizzo, A. B. Fleischer Jr., W. L. White, and J. P. Callen, "Pyoderma gangrenosum: a comparison of typical and atypical forms with an emphasis on time to remission: case review of 86 patients from 2 institutions," Medicine, vol. 79, no. 1, pp. 37-46, 2000.

[4] A. J. Greenstein, H. D. Janowitz, and D. B. Sachar, "The extra intestinal complications of Crohn's disease and ulcerative colitis: a study of 700 patients," Medicine, vol. 55, no. 5, pp. 401-412, 1976. 
[5] L. P. Stolman, D. Rosenthal, R. Yaworsky, and F. Horan, "Pyoderma gangrenosum and rheumatoid arthritis," Archives of Dermatology, vol. 111, no. 8, pp. 1020-1023, 1975.

[6] H. O. Perry and R. K. Winkelmann, "Bullous pyoderma gangrenosum and leukemia," Archives of Dermatology, vol. 106, no. 6, pp. 901-905, 1972.

[7] U. Wollina, "Clinical management of pyoderma gangrenosum," The American Journal of Clinical Dermatology, vol. 3, no. 3, pp. 149-158, 2002.

[8] J. Reichrath, G. Bens, A. Bonowitz, and W. Tilgen, "Treatment recommendations for pyoderma gangrenosum: an evidencebased review of the literature based on more than 350 patients," Journal of the American Academy of Dermatology, vol. 53, no. 2, pp. 273-283, 2005.

[9] M. Regueiro, J. Valentine, S. Plevy, M. R. Fleisher, and G. R. Lichtenstein, "Infliximab for treatment of pyoderma gangrenosum associated with inflammatory bowel disease," The American Journal of Gastroenterology, vol. 98, no. 8, pp. 18211826, 2003.

[10] V. G. Hubbard, A. C. Friedmann, and P. Goldsmith, "Systemic pyoderma gangrenosum responding to infliximab and adalimumab," British Journal of Dermatology, vol. 152, no. 5, pp. 10591061, 2005.

[11] A. Saracino, R. Kelly, D. Liew, and A. Chong, "Pyoderma gangrenosum requiring inpatient management: a report of 26 cases with follow up," Australasian Journal of Dermatology, vol. 52, no. 3, pp. 218-221, 2011.

[12] N. Pereira, M. M. Brites, M. Gonçalo, Ó. Tellechea, and A. Figueiredo, "Pyoderma gangrenosum-a review of 24 cases observed over 10 years," International Journal of Dermatology, vol. 52, no. 8, pp. 938-945, 2013.

[13] D. O. Hasselmann, G. Bens, W. Tilgen, and J. Reichrath, "Pyoderma gangrenosum: clinical presentation and outcome in 18 cases and review of the literature," Journal of the German Society of Dermatology, vol. 5, no. 7, pp. 560-564, 2007.

[14] D. Vidal, L. Puig, M. Gilaberte, and A. Alomar, "Review of 26 cases of classical pyoderma gangrenosum: clinical and therapeutic features," Journal of Dermatological Treatment, vol. 15, no. 3, pp. 146-152, 2004.

[15] P. von den Driesch, "Pyoderma gangrenosum: a report of 44 cases with follow-up," British Journal of Dermatology, vol. 137, no. 6, pp. 1000-1005, 1997.

[16] E. Wilson-Jones and R. K. Winkelmann, "Superficial granulomatous pyoderma: a localized vegetative form of pyoderma gangrenosum," Journal of the American Academy of Dermatology, vol. 18, no. 3, pp. 511-521, 1988.

[17] S. O'Loughlin and H. O. Perry, "A diffuse pustular eruption associated with ulcerative colitis.," Archives of Dermatology, vol. 114, no. 7, pp. 1061-1064, 1978.

[18] R. B. Mlika, I. Riahi, S. Fenniche et al., "Pyoderma gangrenosum: a report of 21 cases," International Journal of Dermatology, vol. 41, no. 2, pp. 65-68, 2002.

[19] M. J. Ye, J. M. Ye, L. Wu, C. P. Keating, and W.-T. Choi, "A challenging diagnosis: case report of extensive pyoderma gangrenosum at multiple sites," Clinical, Cosmetic and Investigational Dermatology, vol. 7, pp. 105-109, 2014.

[20] M. V. Schintler, M. Grohmann, C. Donia, E. Aberer, and E. Scharnagl, "Management of an unfortunate triad after breast reconstruction: pyoderma gangrenosum, full-thickness chest wall defect and Acinetobacter Baumannii Infection," Journal of Plastic, Reconstructive and Aesthetic Surgery, vol. 63, no. 7, pp. e564-e567, 2010. 


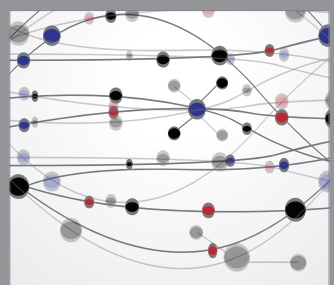

The Scientific World Journal
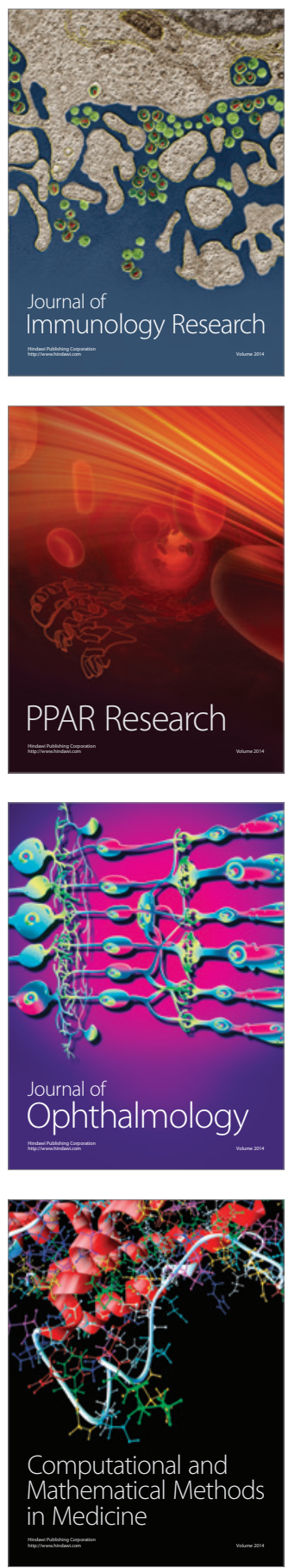

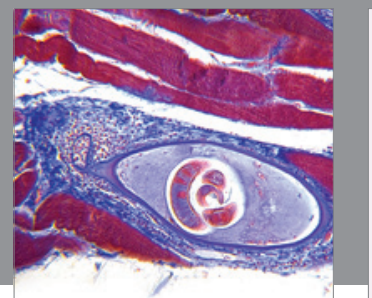

Gastroenterology

Research and Practice
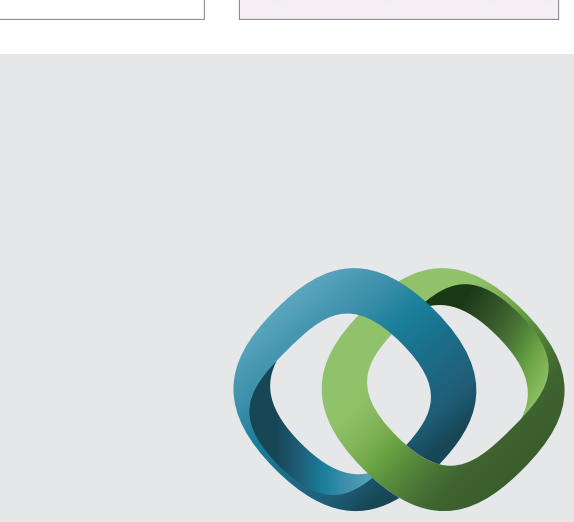

\section{Hindawi}

Submit your manuscripts at

http://www.hindawi.com
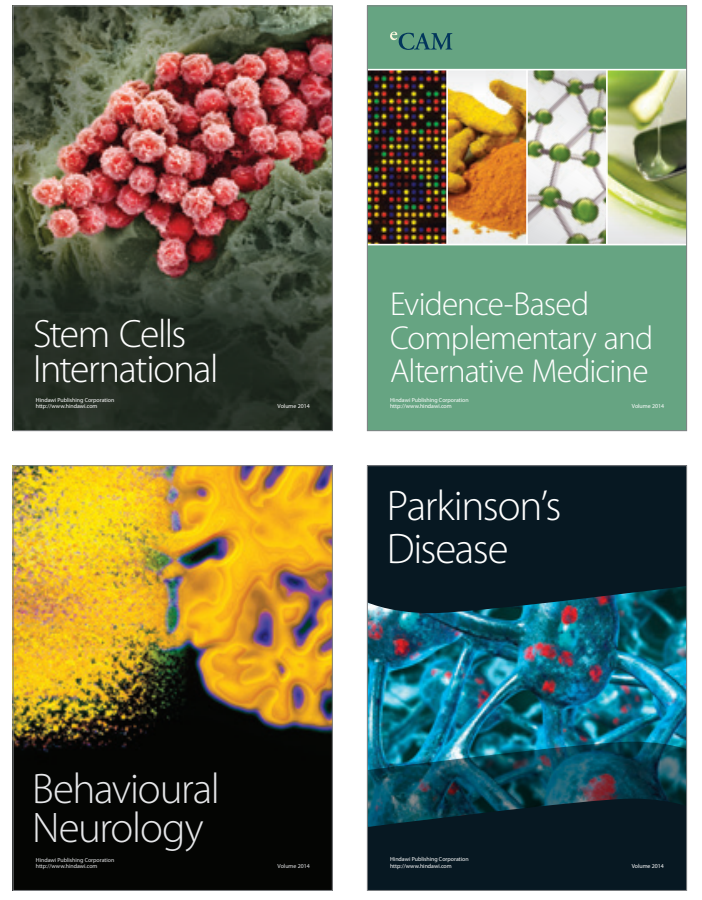
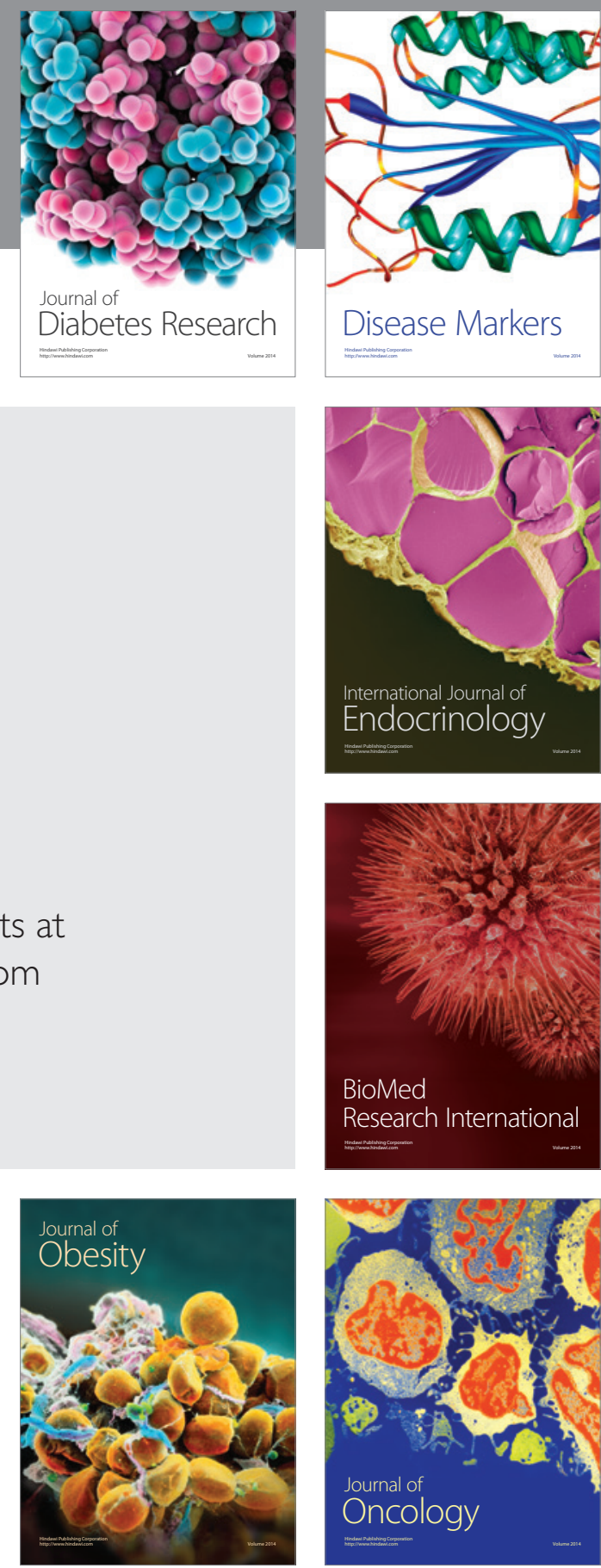

Disease Markers
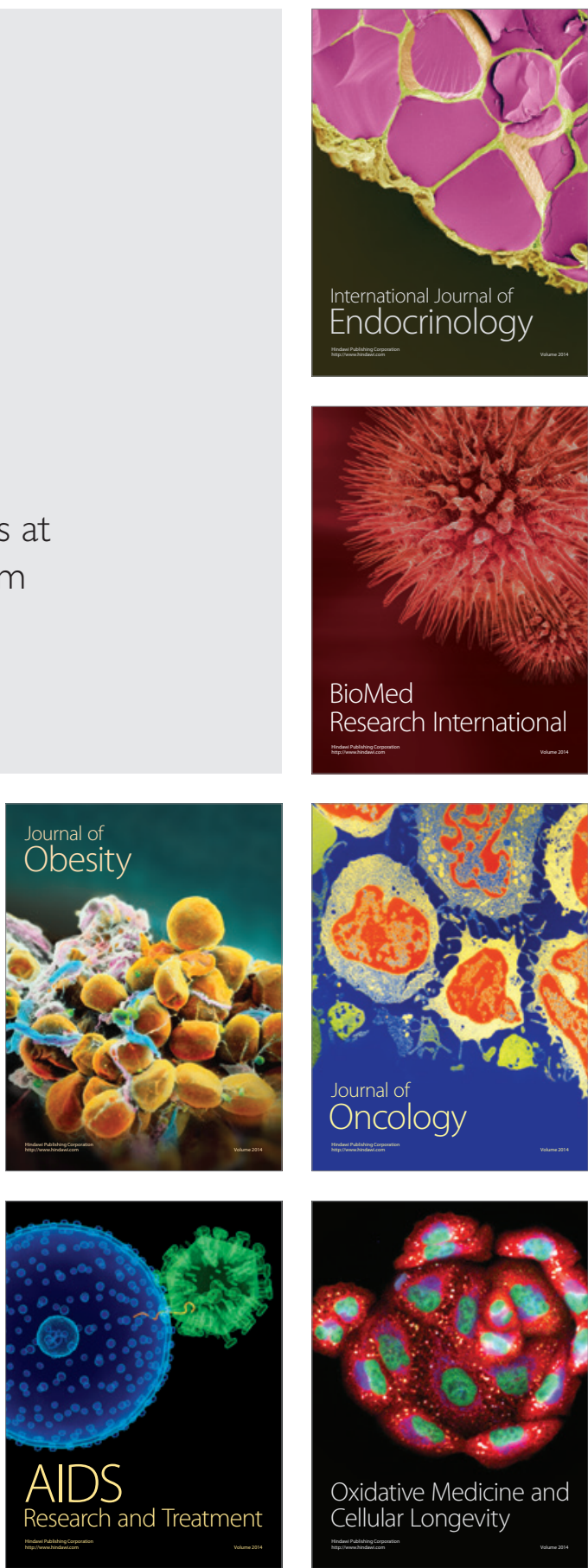